\title{
PMS1 Protein Homolog 1
}

National Cancer Institute

\section{Source}

National Cancer Institute. PMS1 Protein Homolog 1. NCI Thesaurus. Code C21477.

PMS1 protein homolog 1 (932 aa, $106 \mathrm{kDa}$ ) is encoded by the human PMS1 gene. This protein is involved in the repair of DNA mismatches. 